\title{
VISITOR PERCEPTION AND SATISFACTION: The positives and negatives of visiting the Tapajos National Forest Between 2014-2016
}

\author{
Jasmine Cardozo Moreira ${ }^{a}$ \\ Jad Jacqueline Ferraz Bueno ${ }^{b}$ \\ Valéria de Meira Albach ${ }^{c}$ \\ Robert Clyde Burns ${ }^{d}$
}

\begin{abstract}
The Tapajós National Forest (FLONA) is a Conservation Unit (UC) located in the Brazilian Amazon state of Pará. The Flona Tapajos, managed by the Instituto Chico Mendez (ICMBio) has extensive public use (recreation and tourism). In order to identify the negative and positive aspects observed during recreation/tourism visits to the FLONA, an in-person visitor use survey was conducted at the FLONA. As part of a larger study, the objective of this manuscript was to identify the positives and negatives of the visitation pointed out by the visitors of the Tapajós National Forest in the period from 2014 to 2016. A total of 14,291 comments were analyzed, of which 9,004 were positive comments and 5,287 were negative comments. Thematic analysis and a qualitative method was used, and the comments were placed into three categories and 22 subcategorys, according to keywords. The results identify the items that may cause either satisfaction or dissatisfaction by the public. The findings help resource managers better understand the Conservation Unit and the data can support better public use programs and visitation management.
\end{abstract}

\section{KEYWORDS:}

Conservation Unit

Visitors Satisfaction.

Management 


\section{INTRODUCTION}

The Conservation Units in Brazil aim to preserve critically important ecosystems, and in some areas, such as in National Forests, to encourage the sustainable use of their natural resources. They enable the increase of economic activities for the population and its surroundings, adding value and benefiting adjacent communities (BRASIL, 2000).

In 2007, the administration of the federal protected areas was transferred to the Chico Mendes Institute for Biodiversity Conservation (ICMBio) (Law No. 11.516 of August 28, 2007). They are divided into two categories according to management objectives and types of use: Integral Protection Units and Sustainable Use Units. Both categories have as main objective the conservation of the nature. The National Forests are in the Sustainable Use Units category.

The Tapajós National Forest (FLONA) is a federal protected area, created in 1974, located on the banks of the Tapajós River, in Pará. The FLONA receives visitors at the areas where public use is allowed, such as the communities of São Domingos, Maguari and Jamaraquá. It has approximately 527,139 hectares, with more than 160 kilometers of beaches (ICMBio, 2017). The name comes from the Tapajós River, which refers to the Tapajós indigenous people who inhabited the region for centuries.

In addition to its scenic beauty, the area presents interesting sociocultural aspects, represented by the riverside populations and indigenous peoples from the Munduruku ethnic group, divided into three villages: Bragança, Marituba and Takuara (ICMBio, 2017). At the area there is also timber and nontimber production, scientific research, sustainable use projects and environmental education activities.

According to Silva (2015), Maguari community members make great use of their natural resources, such as andiroba tree oil, copaiba tree oil, chestnut, cumaru and cupuaçu fruits, among others. The community members use the resources in a sustainable way and with little degredation to nature. There is also the production of ecological leather handicrafts, the use of non-wood products (e.g., bead necklaces and coin pouches, and ecotourism activities.
The FLONA Management Plan was finalized in 2004, and it has as its primary objective the sustainable use of forest resources and the scientific research. With the tourist activity being increasingly developed in FLONA, some riverside communities felt the need to train residents for tourism. In 2001, many of the FLONA residents under took the "Basic Notions of Tourism Course", and in 2002, they took the course on "Community Management and Organization" (IBAMA, 2004). Other tourism management courses were held involving residents, with one was focused on the planning, implementation and maintenance of trails, resulting in the implementation of interpretive trails at the site. The first interpretive trail implemented was in the community of Maguari, after that other trails were implemented in other communities, which resulted in an increase in the flow of visitors and also increased the tourist offer (IBAMA, 2004).

Knowing about the visitor profile is important information for managers of protected areas. Between 2014 and 2017, the West Virginia University (WVU), in partnership with the US Forest Service - International Programs (USFS-IP) and Ponta Grossa State University (UEPG), developed a research effort entitled "Tourism, Public Use Management and Visitor Perception: Data Collection and Research". A survey was carried out in several federal areas, aiming to obtain data that could be used by managers to propose best practices in tourism and public use management (Lippit et al., 2020).

This research effort was one of the actions that were part of the Partnership for the Conservation of Amazon Biodiversity (PCAB). The US Forest Service (USFS) has worked in partnership with the Brazilian government and civil society for over 40 years. Both the United States and Brazil benefited from this collaboration, and one of the purposes of the partnership was to provide ways to better connect society to public lands through the management of protected areas and the sustainable development of tourism (Lippit et al., 2020).

ICMBio and the USFS-IP defined FLONA Tapajós and Anavilhanas National Park as "demonstrative sites", both in the Amazon region of Brazil. The sites were chosen so that ICMBio could practice what they learned, and after this, begin the implementation in other CUs. Lippit et al. (2020, p.11) suggested that: 
"ICMBio tested it's learning on demonstrative sites, incorporated new concepts and adapted US practices to its own public use and management policies. ICMBio also used its learning to gain more participation from society and incorporate communities in the management of protected areas that surround them. These communities benefited from the growing visitation that better management brought in the form of employment opportunities and economic gain".

At the Flona Tapajós, 4010 face-to-face surveys were conducted with visitors (Burns et al., 2017). The questions were designed to identify the visitor's profile and satisfaction, using a series of Likert scales and openended questions. However, due to the amount of data and the complexity of the analysis, the open questions were not analyzed until now. These questions were the last on the form, and it was the moment when the visitor could comment on what he liked most and what he liked least during his visit.

Accordingly, the objective of this article is to identify the positive and negative comments pointed out by Tapajós National Forest visitors, in the period 2014 to 2016. Specifically, it aims to highlight the importance of analyzing visitor satisfaction in protected areas, through comments from open-ended questions on forms.

\section{METHODOLOGY}

This is a exploratory research, using bibliographical research and field surveys using forms. The analysis method used is qualitative thematic (Cong et al. 2014). The forms were applied directly to visitors, between February 2014 and May 2016 at the FLONA Tapajós, under authorization from SISBIO n. 42819-7 (Moreira \& Burns, 2015; Burns et al. 2017). Tablets and the Droid Survey app were used to collect these primary data. With the app, data was sent to a cloud storage, and accessed for analysis in SPSS Statistic and Excel format. The form was based on the US Forest Service methodology, entitled National Visitor Use Monitoring, the method that the US Forest Service uses to understand visitor use that occurs in National Forests. Each forest collects data with visitors every five years, and in settings categorized as recreational areas, camps, trails, day-use areas, among others (USFS, 2015). In the United States, no open questions are asked.

Due to the richness of the data and the importance of these responses for the public uses analysis, a methodology was created to facilitate. The option was to analyze keywords, grouped into categories according to the positive and negative aspects. Data were categorized in a Excel table, divided into two parts (positive and negative), and categorized into four items: landscape, services, activities and others. Each of these categories has different aspects, presented in subcategorys: such as scenic beauty, access, cleanliness, activities, environmental interpretation, etc. Each subcategory has keywords, which should be identified in each of the comments (Figure 01). This methodology was developed by Albach, Moreira \& Burns (2018), tested by Bueno (2018) and adapted for this research. In addition to open comments in forms, this methodology can also be used to categorize comments on websites such as Trip Advisor or Facebook, for example, as performed by Cong et al., 2014 (natural park); Bizinelli et al., 2013 (beer tourism); Limberger, Boaria \& Anjos, 2014 (hotels) and Silva \& Gândara, 2016 (spas).

Table 1 - Protected Area Categories of Analysis

\begin{tabular}{|c|c|c|}
\hline Category & Aspects & Keywords \\
\hline \multirow[t]{7}{*}{ LANDSCAPE } & $\begin{array}{l}\text { Scenic be- } \\
\text { auty }\end{array}$ & $\begin{array}{l}\text { stunning, wonderful, } \\
\text { incredible scenery, etc. }\end{array}$ \\
\hline & $\begin{array}{l}\text { Nature con- } \\
\text { servation }\end{array}$ & $\begin{array}{l}\text { preserved nature, forest } \\
\text { presence, pristine }\end{array}$ \\
\hline & $\begin{array}{l}\text { Presence of } \\
\text { animals }\end{array}$ & $\begin{array}{l}\text { sightings, contact with } \\
\text { fauna }\end{array}$ \\
\hline & $\begin{array}{l}\text { Landscape } \\
\text { landmarks }\end{array}$ & $\begin{array}{l}\text { geomorphological and } \\
\text { hydrographic elements } \\
\text { (mountains, plateaus, } \\
\text { rivers, etc.) }\end{array}$ \\
\hline & Location & $\begin{array}{l}\text { untouched place, far, } \\
\text { near }\end{array}$ \\
\hline & People & full, empty, crowding \\
\hline & Surroundings & $\begin{array}{l}\text { region, people of the } \\
\text { region, community }\end{array}$ \\
\hline \multirow{4}{*}{ SERVICES } & Buildings & concierge, visitor center \\
\hline & Cleanliness & $\begin{array}{l}\text { dirty, garbage, trash, } \\
\text { clean area }\end{array}$ \\
\hline & Access & good, bad, easy, difficult \\
\hline & Facilities & $\begin{array}{l}\text { parking, wifi, free trans- } \\
\text { port }\end{array}$ \\
\hline
\end{tabular}




\begin{tabular}{|l|l|l|}
\multirow{5}{*}{ SERVICES } & $\begin{array}{l}\text { Interpreta- } \\
\text { tion }\end{array}$ & $\begin{array}{l}\text { panels, video, brochures, } \\
\text { lectures, leaflets }\end{array}$ \\
\cline { 2 - 3 } & Information & $\begin{array}{l}\text { behavior, attractiveness of } \\
\text { the region }\end{array}$ \\
\cline { 2 - 3 } & $\begin{array}{l}\text { Guiding Ser- } \\
\text { vices }\end{array}$ & $\begin{array}{l}\text { service of guides, monitors, } \\
\text { etc... }\end{array}$ \\
\cline { 2 - 3 } & Food & $\begin{array}{l}\text { restaurants, snack bars, } \\
\text { snacks, food quality }\end{array}$ \\
\cline { 2 - 3 } & Prices & $\begin{array}{l}\text { free, price paid, expensive, } \\
\text { cheap. }\end{array}$ \\
\cline { 2 - 3 } & Time & $\begin{array}{l}\text { timetables for activities, } \\
\text { opening and closing time. }\end{array}$ \\
\cline { 2 - 3 } & Shopping & $\begin{array}{l}\text { items for purchase, lack of } \\
\text { items to buy, product high- } \\
\text { lights }\end{array}$ \\
\hline \multirow{5}{*}{ ACTIVITIES } & Souvenirs) & $\begin{array}{l}\text { emergencies, risks, acci- } \\
\text { dents, security, etc. }\end{array}$ \\
\cline { 2 - 3 } & Safety & $\begin{array}{l}\text { trails, baths, experiences, } \\
\text { specific activities in the AP }\end{array}$ \\
\cline { 2 - 3 } & Tourist & $\begin{array}{l}\text { landmark, little visited, all } \\
\text { must know, unique. }\end{array}$ \\
\hline
\end{tabular}

Source: adaptado de Albach, Moreira \& Burns, 2018.

All responses obtained from the surveys were analyzed individually, and according to this keyword criteria. Afterwards, an average of the frequency of answers was elaborated, presented in the results. When comments were longer, in some cases responses were categorized into more than one subcategory.

A total of 5,287 negative comments and 9,004 positive comments were analyzed and categorized according to the classification of specific categories created for this project, described below. Methodologies such as this can be used in other protected areas, facilitating the data analysis to the managers.

\section{THEORETICAL FOUNDATION}

\section{Conservation units}

According to the National System of Conservation Units (SNUC) Law No. 9,985, article 2, Conservation Units are (2000) defined as: "A space and its environmental resources, including jurisdictional waters, with relevant natural characteristics, legally instituted by the Government, with conservation objectives and defined territorial limits, under a special administration, that guarantees the protection".

Santos (2014) notes that research in conservation units is extremely important for several reasons. These settings have natural characteristics, and understanding visitor use is critical to ensure the representation of different populations, habitats and ecosystems and the preservation of the existing biological heritage.

Conservation Units are divided into two categories: total protection and sustainable use. The first are those that allow indirect use of resources, while sustainable settings allow direct use. The Integral Protection Units is the category that encompasses Ecological Stations, Biological Reserves, National Parks, Natural Monuments and Wildlife Refuge. The Sustainable Use Units encompasses the Environmental Protection Areas, Areas of Relevant Ecological Interest, National Forests, Extractive Reserves, Sustainable Development Reserves and Natural Heritage Private Reserves.

There are currently 2,446 Conservation Units cataloged in the Brazilian Registry of Conservation Units (CNUC). Of these, 777 are from the Integral Protection category, 1,669 are Sustainable Use, and 334 are managed by ICMBio (MMA, 2021).

A National Forest allows economic activities to be carried out within the $\mathrm{PA}$, and the local communities are authorized by the government to live in the areas. This type of area allows for public use, which generates resources that enable local improvements and also contribute through environmental education, raising awareness about the importance of environmental conservation.

Tourists, especially those who live in urban areas, often seek nature within natural areas for leisure, recreation to escape their routines. Vallejo $(2013$, p.16) explains that "of all the CUs in the national system, public parks are the most popular and they receive the greatest attention in terms of recreational and tourist use". These areas have unique resources that need protection from to avoid negative impacts. Vallejo goes on to mention that "the activities can also cause negative social and environmental impacts, and may also compromise the characteristics of the areas and the visitation", (2013, p.13). Accordingly, if well managed, the economic activity can generate benefits for both the population and the PA.

The challenges for the management of public use in PAs are diverse, including human resources, financial resources and the ability to monitor and limit public 
use (Fontoura, Medeiros \& Adams, 2016) infrastructure for public use, implementation of management plans or equivalent management tools, as well as few staff to serve the public (Pires \& Rugine, 2018). Thus, data and information that support management are important (Malta \& Costa, 2009) and through the visitor profile and visitation characteristics such as perceptions, satisfactions and reactions, PA managers could avoid conflicts of use and environmental impacts.

Because the tourism can potentially cause negative impacts in the PAs, it is necessary to implement monitoring and public use management in order to minimize the impacts of visitation. Public use activities can be carried out in a variety of ways. Thus, the knowledge of visitor satisfaction, their profile, characteristics and how often the area is visited are important elements to assist the management of the PA.

\section{Visitor profile and satisfaction}

Kotler (2000, p. 58) suggests that "satisfaction is the feeling of pleasure or disappointment resulting from the comparison of the performance (or result) perceived by a product in relation to your expectations."

Visitor satisfaction is essential in order to leverage the service offered at the site and for improvements to be made based on this data collection. According to Panosso Netto and Gaeta (2010), tourist satisfaction is considered an indicator that allows evaluating the extent to which the experience meets expectations. In this context, satisfaction is a feeling that results from the visitor's expectations, who will conclude according to these expectations whether he felt satisfied or not.

The analysis of this satisfaction is useful for managers, as visitors analyze the environment in a more delicate way, according to their feeling at that moment. Given that satisfaction will depend on the positive and negative influences that the visitor had as an experience and also on the expectations regarding the place, Lovelock $\&$ Wright (2006) state that before the purchase, customers have an expectation based on their individual needs, experiences recommendations, third-party recommendations, and advertising from a service provider.

Satisfaction is the degree to which the service meets or exceeds the expectations of consumers who will judge the service according to the quality of the service provided. Kotler \& Armstrong (2007) define satisfaction as what the customer perceives in relation to the product's performance compared to their expectations. If this performance does not match the expectations, he will be dissatisfied and if it does, he will be satisfied. If it exceeds expectations, the customer will be "extremely satisfied" or "delighted".

According to Zucco, Magalhães \& Moretti (2010) the satisfaction survey can reveal aspects that tend to contribute to better services, this evaluation being constant brings benefits as a way to feed back and control management efforts from the point of view of customers, and in this case of visitors. Farias et al. (2017) states that the bigger and better the structure and the service, the greater the customer satisfaction, so there is an increase in their disclosure, which ends up contributing to attracting more visitors and consolidating the advertising of a tourist product. Santos $(2013$, p. 524) emphasize that "satisfying tourists can be considered an intermediate objective for increasing future demand, as higher levels of satisfaction imply more word-of-mouth and greater advertising tourist loyalty".

\section{RESULTS AND DISCUSSIONS}

In the survey conducted between 2014 and 2016 at FLONA Tapajós, 4,010 people were interviewed using forms in tablets. According to Burns et al. (2017), the profile identified for the FLONA was that approximately half of the public was female $(51.7 \%)$, half of the respondents (50.3\%) were between 21-40 years old, $69.9 \%$ reported having complete higher education or postgraduate studies and $69.6 \%$ of respondents were Brazilians from the State of Pará (mainly from the city of Santarém), followed by São Paulo. Among foreigners, most had come from France (15.8\%), the United States (15.2\%) and the United Kingdom (13.9\%). The majority of visitors (85.9\%) were visiting the FLONA for the first time and $63.2 \%$ were in groups composed of families and/or friends. The área was acessed by car (24.7\%), the speedboat (23.7\%), and small boat (15.9\%).

- Positive and negative comments analysis 
The authors analyzed 5,287 negative comments and 9,004 positive comments about FLONA Tapajós. This value differs from the total number of forms obtained because as it was an open question, some answers were longer and categorized as more than one comment. Figure 2 shows the results, in percentage and according to the methodology used.

Figure 2: What you liked most and least about FLONA Tapajós?

\begin{tabular}{|c|c|c|c|c|c|}
\hline Category & $\begin{array}{l}\text { Subcate- } \\
\text { gorys }\end{array}$ & $\begin{array}{l}\text { Liked } \\
\text { Least }\end{array}$ & $\%$ & $\begin{array}{l}\text { Liked } \\
\text { Most }\end{array}$ & $\%$ \\
\hline \multirow{7}{*}{ Landscape } & Scenic be- & 106 & 2,0 & 2212 & 24,6 \\
\hline & $\begin{array}{l}\text { Nature } \\
\text { Conserva- } \\
\text { tion }\end{array}$ & 194 & 3,7 & 305 & 3,4 \\
\hline & $\begin{array}{l}\text { Presence of } \\
\text { animals }\end{array}$ & 418 & 7,9 & 625 & 6,8 \\
\hline & Landscape & 368 & 7,0 & 2194 & 24,4 \\
\hline & Location & 105 & 2,0 & 92 & 1,0 \\
\hline & People & 142 & 2,7 & 674 & 7,6 \\
\hline & $\begin{array}{l}\text { Surroun- } \\
\text { dings }\end{array}$ & 73 & 1,4 & 311 & 3,4 \\
\hline & Subtotal & 1.406 & $\begin{array}{c}26,7 \\
\%\end{array}$ & 6.413 & $\begin{array}{c}71,2 \\
\%\end{array}$ \\
\hline \multirow{12}{*}{ Service } & Buildings & 92 & 1,7 & 34 & 0,4 \\
\hline & Cleanliness & 674 & 12,8 & 24 & 0,3 \\
\hline & Access & 617 & 11,7 & 09 & 0,1 \\
\hline & Facilities & 411 & 7,8 & 50 & 0,5 \\
\hline & $\begin{array}{l}\text { Environ- } \\
\text { mental } \\
\text { Interpreta- } \\
\text { tion }\end{array}$ & 194 & 3,7 & 25 & 0,3 \\
\hline & Information & 169 & 3,2 & 49 & 0,5 \\
\hline & Guiding & 70 & 1,3 & 191 & 2,1 \\
\hline & Food & 260 & 4,9 & 158 & 1,7 \\
\hline & Prices & 160 & 3,0 & 04 & 0,1 \\
\hline & $\begin{array}{l}\text { Operation } \\
\text { Hours }\end{array}$ & 28 & 0,5 & 01 & - \\
\hline & $\begin{array}{l}\text { Shopping } \\
\text { (souvenirs) }\end{array}$ & 18 & 0,3 & 35 & 0,4 \\
\hline & Safety & 50 & 0,9 & 14 & 0,1 \\
\hline & Subtotal & 2.743 & $\begin{array}{c}51,8 \\
\%\end{array}$ & 594 & $6,5 \%$ \\
\hline
\end{tabular}

\begin{tabular}{|l|l|c|c|c|c|}
\multirow{2}{*}{ Activities } & Activities & 171 & 3,2 & 987 & 11,0 \\
\cline { 2 - 6 } & Tourist at- & 84 & 1,6 & 45 & 0,5 \\
\hline & Subtotal & 179 & $\begin{array}{c}4,8 \\
\%\end{array}$ & 1032 & 11,5 \\
\hline Others & $\begin{array}{l}\text { Subcate- } \\
\text { gorys }\end{array}$ & 883 & 16,7 & 965 & 10,8 \\
\hline Total & & 5287 & $\begin{array}{c}100 \\
\%\end{array}$ & 9004 & $\begin{array}{c}100 \\
\%\end{array}$ \\
\hline
\end{tabular}

Source: Authors.

The results show that, among the negative aspects, the category that stood out was "Cleanliness" with 674 negative comments, and the category least commented on was "Shopping (souvenirs)" with only $18 \mathrm{com}$ ments.

Regarding the positive comments, the most noted category was "Scenic Beauty" with 2212 positive comments about the landscapes of FLONA, and the least commented was "Operating Hours", with only one comment about the waiting time for the activities.

Based on the information collected, some observations were made about what the visitor liked the most and what he liked least, categorized into the categories: landscape, services, activities and others.

- What you liked least:

- Landscape Category

In the Landscape category, the total of negative comments was $26.7 \%$. Presence of Animals were the most commented on, with 418 (7.9\%) comments and in second place Landscape Landmarks, with 368 (7\%) of the comments.

Regarding the scenic beauty comments, some visitors commented that: "the bridge to the igarapé is closed, so the visitors can't visit the place, not enought time to visit the igarapés and the "sumaúma" tree, lack of information about the flora, litter, improve the trails". In the Nature Conservation subcategory, some visitors pointed out that: "there are áreas in the forest that are destroyed" and commented on the pollution: "The water was with oil" and "there is a gas station near the bathing area", observed shards of glass left in the sand and degraded roads.

Regarding the Wildlife category, visitors complained about the insects: spiders, cockroaches, wasps, flies, bees, ants, etc., which ended up biting some visitors; 
animals like stingrays, frog noise, snakes on the trail, horses on the beach. One of the comments was about "people cooking a turtle in a barbecue". Others were: "strong smell of fish; illegal hunting of animals; absence of fauna (mainly birds); and a beach soiled by animal waste".

The subcategory Landmarks of Landscape included most of the comments about the region's climate, which is typical of the Amazon: "a lot of rain disturbed the tour; strong sun; too much heat and humidity in the place; water fluctuation"; Other people commented that they preferred the flood season or the dry season, or that because of the flood, the beach could not be visited. In Location, they complained mainly about the distance and lack of signage. In the People subcategory, visitors commented on the overcrowding of visitors causing congestion, turmoil, in addition to the excess of cars and motorcycles; also complained about: "people consuming alcoholic beverages, and "annoying teenagers" in the region"; In the Service subcategory, comments were about the education of employees, locals misunderstanding in front of visitors, the slow service at the inns; loud sound, and locals pressuring tourists to buy tours.

Regarding the surroundings, comments were noted about the fact that the local culture is not preserved and valued (such as non-traditional and non-standard buildings), the lack of public policies and "noise from political campaigns, cars and churches with loud sound "; the lack of environmental education, the lack of garbage collection in the communities and the precariousness of life in the place.

\section{- Services Category}

In this category, $51.8 \%$ of visitors who made a negative comment showed dissatisfaction. They observed as the main negative points the Cleanliness, with 674 (12.8\%) comments, followed by Access with 617 (11.7\%) and Facilities with 411 (7.8\%) negative comments.

In the Buildings subcategory, most comments were about the precarious infrastructure, the lack of parking, guides, visitor center, and some inns that were closed. In Cleanliness, comments were largely about pollution, dirty beaches, garbage, plastic bags, paper and cans on the trail; open sewers; lack of dumps; bathrooms with bad smell or without water; lack of environmental awareness of local people and poor waste collection in communities. In Access, visitors complained about the difficulty of accessing the area, the lack of signage, potholes in the road, not enough public transport, lack of accessibility for the disabled and the elderly and steep trails. In Facilities, they mentioned the lack of businesses near the PA that accept credit/debit cards; lack of accommodation for tourists with toilets with hot water; lack of a nearby health center; poor cell phone and internet coverage; unsustainable electricity and, finally, the lack of air conditioner in some places. Regarding Environmental Interpretation, the visitors commented about the lack of printed material, posters, panels, historical and scientific information; options in other languages and a better identification of attractions. The Information comments were generally about the lack of information and the possibilities of tours that could be taken.

In the Guides subcategory, some commented on the obligation of having a guide to do the tours; the lack of guides who speak another language; and the amount charged by the guides. In Food, the comments were mainly about the lack of restaurants near or in the area, no diversity of food; the delay in serving and the lack of a more local breakfast. About Prices, visitors complained about the prices in general: that the price of hotels and inns should be more flexible and also the prices for the transportation to the FLONA. In Operation Hours, the comments were about waiting to do the tours and limited bus schedules. In Shopping, the comments were about the lack of handicrafts to sale. And finally in Security, some visitors expressed concern about the lack of police in the region, dangerous trails and unprotected wells.

\section{- Category Activities/Others}

In the Activities category, only $4.8 \%$ of visitors commented something about the activities offered. In the Others subcategory, $16.7 \%$ didn't like anything else on FLONA. Some comments were about lack of leisure options and other activities that could be available; the lack of options during the flood period; and the lack of more water activities. In Tourist Attraction they commented on the few options, and that just a few were open to visitation. Others were comments that did not fit into any other category, such as comments about 
the time spended to answer this survey; the lack of professionalism in the hotel industry in Santarém and the amount of vehicles at the FLONA.

-What you liked the most:

Landscape Category

This is the category that has most comments, totaling $71.2 \%$ of all positive comments. The Scenic Beauty (24.6\%) is followed by Landscape Landmarks (24.4\%), both linked to natural aspects. The comments on Scenic Beauty were about the beautiful natural landscapes, the size of the Tapajós River; the biodiversity beauty; the color of the water in the rivers, the exuberance of the forest; contact with nature; the beauty of communities; the purity of the air, among others. In Nature Conservation, the comments were mainly about fauna and flora preservation, conservation and maintenance of the area. In Presence of Animals, the comments were about the opportunity to approach and interact with wild animals; the existence of a night activity; the opportunity to see alligators, squirrels, lizards, monkeys, fish, snakes, spiders, turtles, sloths, birds, butterflies, among others. In Landscape Landmarks there were comments about the tree called in the region "Vovó Sumaúma"; the igapós and igarapés preservation; the variety of vegetation; and that the trails were in good condition. In People, the comments were about residents, communities, receptiveness, kindness, and good service; environmental awareness and appreciation of local culture. Finally, in Surroundings, the comments were about the rubber tapping "seringueiros" way of life and the fact that the communities participate in the organization of FLONA.

Services Category

In this item, the total percentage of responses obtained was only $6.5 \%$, which demonstrates that this category is not the Unit's strong point. Guides had only $2.1 \%$ of the comments and Food, 1.7\%. In Buildings, visitors mentioned the infrastructure. In Cleanliness, they commented that the trails, beaches an rivers were clean. In the item Facilities, they commented on FLONA's small facilities, including the reception of visitors. In the Environmental Interpretation subcategory, they mentioned the guides and the interpretation that includes explanations about the native use of trees and medicinal plants. In Information, they commented on the tradi- tional knowledge; correct informations about the area, clearly conveyed; In Guides, what visitors liked the most was the dedication of the guides, in addition to their professionalism, receptivity and environmental awareness. In Food, the comments were about regional food and local cuisine; and the variety of restaurants with rustic feeling. In Shopping (souvenirs), visitors reported that they enjoyed visiting where the latex is manufactured; the biojewel work of the community women's group; handicrafts made with natural elements; and the Craft Center in the region. And finally, in the Security subcategory, they commented on feeling safe in nature; the depth of the waters that is safe for children; and the availability of emergency care when minor accidents happen.

\section{Activities/Others Categories}

In Activities, $11.5 \%$ of visitors answered what they liked most (987 comments) and $10.8 \%$ were classified in the Others category. The comments were about bathing in the river, trails, water trail, boat trips through the igapós, night boat trips, night aligátor spotting, camping in the forest, visit the handicraft shop; and learn more about the latex extraction. In Tourist Attractiveness, the comments were on: sumaúma tree, community-based tourism; and learn about the production of Latex and flour. The Others category present comments that do not apply to other categories, among them were: peace, calm and authenticity, learning about native medicine; primitive, charming, comfortable, well-run place; and excellent for relaxing and unwinding.

\section{Final Considerations}

It was observed that, in total, the positive comments (9004) stood out from the negative comments (5287), which suggests that most of the visitors enjoyed the visit. They value the Amazonian landscape and the way of life of the communities. This research did not intend to judge or justify the comments presented, but rather to provide managers with general data on the categories.

The results using this methodology showed a positive highlight for the comments in the subcategorys of Scenic Beauty (24.6\%) and Landscape Landmarks (24.4\%). 
In total, the Landscape category had $71.2 \%$ of the comments. The most significant negative comments were from the subcategorys Others, with $16.7 \%$ and Cleanliness, with $12.8 \%$. The Services category had the most negative comments, with more than half of the comments, totaling $51.8 \%$.

Many of this suggestions observed in the comments can help the managers. Among them are the improvement of signage, the implementation of environmental interpretation panels, improve the website including information such as prices, tours, distances and transport. Regarding cleanliness, the suggestion is that garbage collection should be more frequent, the need of more trash cans, and the creation of environmental awareness programs for visitors. In some cases, these are suggestions that do not depend exclusively on the PA, such as improving access roads, or the quality of service at hotels in Santarém.

The limitations observed in this research could be minimized during the training of those responsible for data collection. One of the biggest difficulties encountered was the fact that in open questions, even if the word is the same, if it is written with a capital letter, the software analyzes it as a different word, even if it is the same word starting with a lowercase. This differentiation makes the analysis take longer. In addition, it is important to have knowledge of these software, for the correct performance of the analysis.

Regarding the categorizing comments methodology, it is observed that it can be used by other PAs. Some categories could be revised and adapted, such as the Environmental interpretation category and the Guide category. In some PAs there are self-guided trails and, therefore, guiding services are not necessary. In addition, as the analysis is performed, more keywords can be added, depending on the specificity of each area.

Also related to the methodology and to facilitate the data analysis, the suggestion is to create general categories related to what you liked most and least in the forms and use it already during the interview. Closed questions are easier to tabulate.

\section{REFERENCES}

Albach, V. M.; Moreira, J. C.; \& Burns, R. (2018). Methodological proposal for the analysis of the 'online reputation' of protected areas In: Abstract Book The 9th International Conference on Monitoring and Management of Visitors in Recreational and Protected Areas (MMV9), (p. 475-476). Bordeaux: Bordeaux Science Agro.

Bizinelli, C., Manosso, F. C., Gândara, J. M. G., \& Valduga, V. (2013) Experiências de Turismo Cervejeiro em Curitiba, PR. Revista Rosa dos Ventos, 5 (2), p. 349-375.

Burns, R. C.; Moreira, J. C.; Chupinkro, T.; \& Gregory, L. (2017) Flona Tapajós: Pesquisa Sobre Recreação e Uso Público. (Relatório Final). Morgantown: WVU.

Bueno, J. F. (2018). A satisfação dos visitantes nas Unidades de Conservação: uma comparação entre o Parque Naciona de Anavilhanas (AM) e a Floresta Nacional do Tapajós (PA). (Trabalho de Conclusão de Curso Graduação). Curso de Turismo, Universidade Estadual de Ponta Grossa.

Cong, L.; Wu, B.; Morrison, A. M.; Shu, H.; \& Wang, M. (2014). Analysis of wildlife tourism experiences with endangered species: An exploratory study of encounters with giant pandas in Chengdu, China. Tourism management, 40, $p$ 300-310.

Farias, P. P.; Pederneiras, M. M. M.; Silva, K. G. S.; \& Silva, E. R. "Paraíso natural nas águas": o nível de satisfação dos consumidores em relação aos passeios de barco à Picãozinho. Applied Tourism. 2 (3), 2017, p. 136-155.

Fontoura, L. M.; Medeiros, R. J.; \& Adams, L. W. (2016). Turismo, pressões e ameaças para a conservação da biodiversidade em parques nacionais do Brasil e Estados Unidos. CULTUR: Revista de Cultura e Turismo, 10(1), 35-53.

IBAMA. (2004). Floresta Nacional do Tapajós: Plano de Manejo. Pará, 2004. vols. I, II, III, IV. Recuperado em 01 de maio de 2018, de http://www.icmbio.gov.br/portal/ unidadesdeconservacao/biomas-brasileiros/amazonia/ unidades-de-conservacao-amazonia/1963-FLONA-dotapajos.

ICMBio. (2017). A Floresta Nacional de Tapajós. Recuperado em 19 de outubro de 2017, de http://www.icmbio.gov.br/ FLONAtapajos/.

Kotler, P. (2000). Administração de Marketing: análises, planejamento, implementação e controle. São Paulo: Atlas, 2000.

Kotler, P. \& Armstrong, G. (2007). Princípios de Marketing. São Paulo: Pearson Prentice Hall.

Lei Federal no 11.516 de 28 de agosto de 2007. Dispõe sobre a criação do Instituto Chico Mendes de Conservação da Biodiversidade - Instituto Chico Mendes; altera as Leis nos 7.735, de 22 de fevereiro de 1989, 11.284, de 2 de março de 2006, 9.985, de 18 de julho de 2000, 10.410, de 11 de janeiro de 2002, 11.156, de 29 de julho de 2005, 11.357, de 19 de outubro de 2006, e 7.957, de 20 de dezembro de 1989; revoga dispositivos da Lei no 8.028, de 12 de abril de 1990, e da Medida Provisória no 2.216-37, de 31 de agosto de 2001; e dá outras providências. Recuperado de http://www.planalto.gov.br/ccivil 03/ Ato2007 